\title{
Phototactic Response of Aerobically Cultivated Rhodospirillum rubrum
}

\author{
By S. HARAYAMA AND T. IINO \\ Laboratory of Genetics, Faculty of Science, University of Tokyo, Hongo, \\ Tokyo, Japan
}

(Received I4 August 1975)

\begin{abstract}
SUMMARY
Motile cells of aerobically cultivated Rhodospirillum rubrum, containing no detectable bacteriochlorophyll, assembled at a spot of strong light projected through a dark-field condenser. Far-red light was not effective, indicating that bacteriochlorophyll and thus photosynthetic metabolism was not responsible for the phenomenon. Bacteria moving towards the centre of the light spot changed direction less frequently than those moving towards the margin. They also responded to temporal changes in the intensity of light, altering their swimming direction more frequently after a sudden decrease in light intensity than after an abrupt increase.
\end{abstract}

\section{INTRODUCTION}

Phototaxis in photosynthetic bacteria was first described by Engelmann (I883). Since then, investigations of bacterial phototaxis have been carried out mainly with Rhodospirillum rubrum, a species of non-sulphur purple bacteria (for reviews, see Clayton, 1959; Nultsch, 1970). The action spectra for phototaxis of this species have been reported by Clayton (1953a) and Milatz \& Manten (1953) and they coincide with those for photosynthesis (French, 1937; Thomas, 1950). From these results, Manten (I948) proposed that phototaxis is a reaction associated with a quick change in the rate of photosynthesis, and his hypothesis has been widely accepted (Clayton, 1959, 1964; Haupt, 1966; Nultsch, 1970; Thimann \& Curry, 1960).

In chemotaxis of bacteria, the idea of perception and transmission of chemotactic stimuli through the metabolism of attractants had long been believed. However, Adler and his coworkers (Adler, 1966, 1969; Adler \& Epstein, 1974; Hazelbauer \& Adler, 1971) showed that for Escherichia coli the necessary factor for chemotaxis was not the metabolism of attractants but their interaction with chemoreceptors (see also Aksamit \& Koshland, 1974; Hazelbauer, 1975). This poses the question of whether light acts as a stimulus for phototaxis in $R$. rubrum without the mediation of photosynthetic metabolism.

'Phototaxis' in non-photosynthetic bacteria was first described as early as 1920 by Metzner. The bacterium, Spirillum volutans, was treated with photosensitizing dyes and showed a phototactic response which was maximal at the wavelength of maximum absorption of light by the dye. One interpretation of this phenomenon was that dye-mediated photodynamic action evoked a tactic response (Clayton, 1964). Recently, Macnab \& Koshland (1974) reported that a high-intensity light pulse induced tumbling, i.e. interruption of smooth swimming, in Salmonella typhimurium. This was not due to photodynamic action, because histidine, which prevents such action, had no effect.

This paper describes a light-induced tactic response in $R$. rubrum which was cultivated aerobically so that synthesis of photosynthetic pigments would be repressed. 


\section{METHODS}

Organism. Rhodospirillum rubrum IFO3986, a stock culture of the Institute for Fermentation, Osaka, Japan, was obtained through the kindness of Dr T. Iijima of that Institute.

Culture conditions. The semi-synthetic medium of Cohen-Bazire, Sistrom \& Stanier (1957) was used with slight modification. The composition, per litre, was: DL-malic acid $(2.68 \mathrm{~g}), \mathrm{NaOH}(\mathrm{I} \cdot 60 \mathrm{~g}), \mathrm{K}_{2} \mathrm{HPO}_{4}(87 \mathrm{I} \mathrm{mg}), \mathrm{KH}_{2} \mathrm{PO}_{4}(680 \mathrm{mg}),\left(\mathrm{NH}_{4}\right)_{2} \mathrm{SO}_{4}(\mathrm{I} \cdot 32 \mathrm{~g})$, $\mathrm{MgSO}_{4} \cdot 7 \mathrm{H}_{2} \mathrm{O}\left(247 \mathrm{mg}\right.$ ), $\mathrm{CaCl}_{2}(55.5 \mathrm{mg}), \mathrm{ZnSO}_{4} \cdot 7 \mathrm{H}_{2} \mathrm{O}$ (I4.4 mg), $\mathrm{FeSO}_{4} \cdot 7 \mathrm{H}_{2} \mathrm{O}(5.62 \mathrm{mg}$ ), $\mathrm{MnSO}_{4} \cdot \mathrm{H}_{2} \mathrm{O}(\mathrm{I} \cdot 69 \mathrm{mg}), \mathrm{CuSO}_{4} \cdot 5 \mathrm{H}_{2} \mathrm{O}(0.50 \mathrm{mg}), \mathrm{Co}\left(\mathrm{NO}_{3}\right)_{2} \cdot 6 \mathrm{H}_{2} \mathrm{O}(0 \cdot 29 \mathrm{mg}), \mathrm{Na}_{2} \mathrm{~B}_{4} \mathrm{O}_{7}$. ${ }_{10 H_{2}} \mathrm{O}(0 \cdot 19 \mathrm{mg}),\left(\mathrm{NH}_{4}\right)_{6} \mathrm{Mo}_{7} \mathrm{O}_{24} \cdot 4 \mathrm{H}_{2} \mathrm{O}(0 \cdot 25 \mathrm{mg})$, nicotinic acid $(\mathrm{I} \cdot 23 \mathrm{mg})$, thiamine- $\mathrm{HCl}$ $(0.34 \mathrm{mg})$, biotin (0.012 mg), vitamin-free casamino acids (Difco) (I g).

Bacteria were inoculated into $100 \mathrm{ml}$ of medium in a $500 \mathrm{ml}$ Erlenmeyer flask and grown aerobically at $30{ }^{\circ} \mathrm{C}$ on a reciprocating shaker at 80 strokes $/ \mathrm{min}$. Cells at early to midexponential growth phase with a generation time of about $4 \mathrm{~h}$ were used for all experiments. Intracellular bacteriochlorophyll under these conditions, as measured by the method of Taniguchi \& Kamen (1965), was less than 10 nmol per mg of bacterial protein.

Observation of bacteria in a light spot. Bacteria suspended in the semi-synthetic medium were delivered under the coverslip of a bacterial counting chamber, depth $20 \mu \mathrm{m}$. A light beam from a tungsten-halogen lamp (JC-I5V-I20W or JC-24V-I5oW, Ushio Electric Co. Ltd, Tokyo, Japan) was passed through appropriate filter(s) (HA-50 or R-72, Hoya Glass Works, Tokyo, Japan) and projected on to the suspension through a dark-field condenser (UV-superwide, Tiyoda Optical Co. Ltd, Tokyo, Japan) to make a light spot. All observations were made at $25^{\circ} \mathrm{C}$.

Measurement of swimming speed. Swimming tracks of bacteria were recorded cinematographically with one-second exposures on $16 \mathrm{~mm}$ film (Plus-X negative, Eastman Kodak Company, Rochester, U.S.A.). Swimming speeds were estimated from the lengths of the tracks.

Recording the path of the swimming bacteria. Bacterial movements under steady illumination or with an abrupt change of intensity were cinematographed on Eastman Plus-X film at a speed of $\mathrm{I} 2$ frames per second. To reduce light intensity, a neutral density filter (Hoya ND-50) was inserted between the lamp and the mirror of the microscope. The paths of representative bacteria were traced from the cinematograms and frequencies of turns in swimming direction within a given time were determined from the tracks.

Measurement of light energy impinging on bacteria. It was difficult to estimate the light intensity of a given small area within the spot and so only the mean value of light intensity of the spot was measured. This was done with a photoreceiver $(1 \cdot 2 \mathrm{~mm}$ diameter $)$ with two copper-constantan thermocouples (Omega Engineering Inc., Stanford, U.S.A.) coated with optical black lacquer (Colonial Lacquer and Chemical Co. Inc., Ashland, U.S.A.).

\section{RESULTS}

\section{Effect of light on bacterial assembly}

Swimming cells of $R$. rubrum cultivated aerobically in the dark assembled in the light spot projected through a dark-field condenser. During this period changes in bacterial density within the light spot were photographically recorded and concentration was estimated by counting the numbers in a $450 \times 600 \mu \mathrm{m}$ rectangular area of the light spot. The condenser was centred and focused on the objective plane at the onset of each experiment and the first photograph taken 2 min later. 

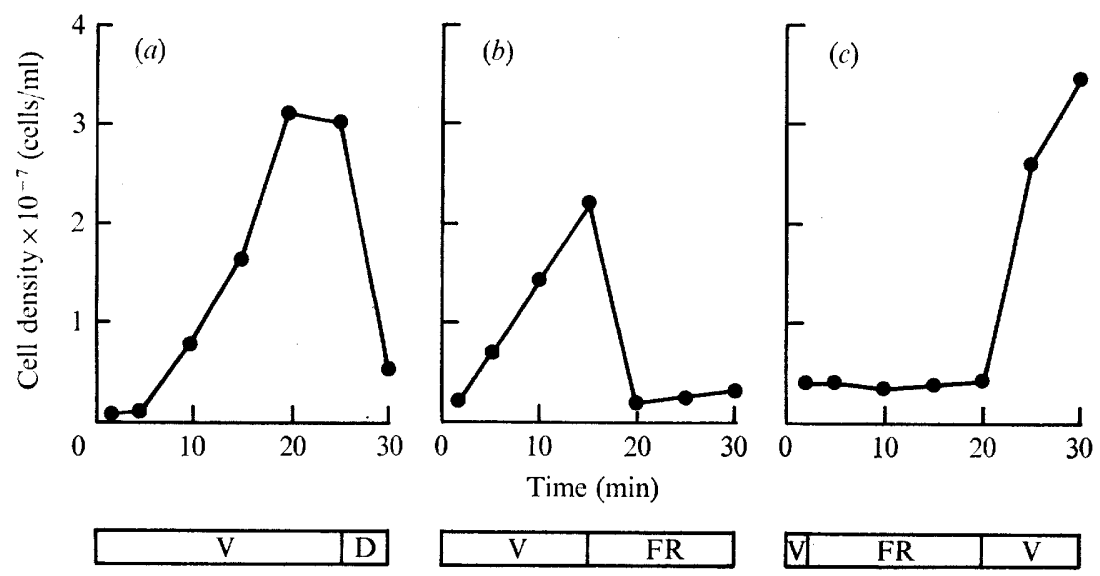

Fig. I. Effects of visible and far-red light on bacterial assembly. Each diagram is a plot of the bacterial concentration within the area of the light spot against the duration of illumination. (a) At o time, projection of visible light was started and was continued for $25 \mathrm{~min}$, finishing with $5 \mathrm{~min}$ of darkness. (b) Visible light was projected for the first $15 \mathrm{~min}$, and was then replaced by far-red light. At 20,25 and $30 \mathrm{~min}, 5 \mathrm{~s}$ of visible light was projected for photography. (c) For the first $2 \mathrm{~min}$, visible light was projected, then far-red light for $18 \mathrm{~min}$ and visible light for a further $18 \mathrm{~min}$. At 5 , Io and $\mathrm{I} 5 \mathrm{~min}, 5 \mathrm{~s}$ of visible light was projected for photography. The light source was a tungstenhalogen lamp (JC-15V-I2OW) with two HA-50 filters (visible light) or one R-72 filter (far-red light). V, Visible light; D, darkness; FR, far-red light.

Some representative results are shown in Fig. I. The concentration of bacteria in the spot of visible light $(350-900 \mathrm{~nm})$ of $3 \mathrm{~J} \mathrm{~cm}^{-2} \mathrm{~s}^{-1}$ increased after the onset of illumination, but assembled bacteria started to disperse when the stimulating light was removed (Fig. I $a$ ). When visible light was replaced after 2 min with far-red light (above $700 \mathrm{~nm}$ ) of $4 \mathrm{~J} \mathrm{~cm}^{-2} \mathrm{~s}^{-1}$, bacteria did not start to assemble in the light spot until the far-red light was again replaced with visible light (Fig. I $c$ ). These results clearly indicate that visible light, but not far-red light, was effective in assembling bacteria.

When a bacterial suspension of relatively high density $\left(2 \times 10^{7}\right.$ cells $\left./ \mathrm{ml}\right)$ was used, the number of cells in the light spot began to increase immediately, but 16 min after onset of illumination, assembled bacteria started to migrate out of the centre of the light even if the illumination was constant (Fig. 2). This may be a reaction of the bacteria to the oxygen gradient formed by their respiration (Adler, I966).

\section{Speed of movement of bacteria in a light spot}

The assembly of freely moving micro-organisms towards a stimulus could be attained either by taxis or by kinesis. Kinesis is a response in which organisms change their speed on receiving the stimulus, while taxis involves a change in swimming direction (Haupt, 1966). To investigate which phenomenon was operating in $R$. rubrum, the swimming tracks of bacteria in the central and peripheral areas of a light spot were recorded cinematographically (Fig. 3). As the bacteria moved towards the centre of the light spot, the difference in density in the two areas became obvious (Fig. $3 b$ ). The swimming tracks of bacteria in both areas were traced on the photographs taken from 2 to 2.5 min after the start of illumination. The mean speeds of the bacteria in the two areas were identical (Fig. 4). 

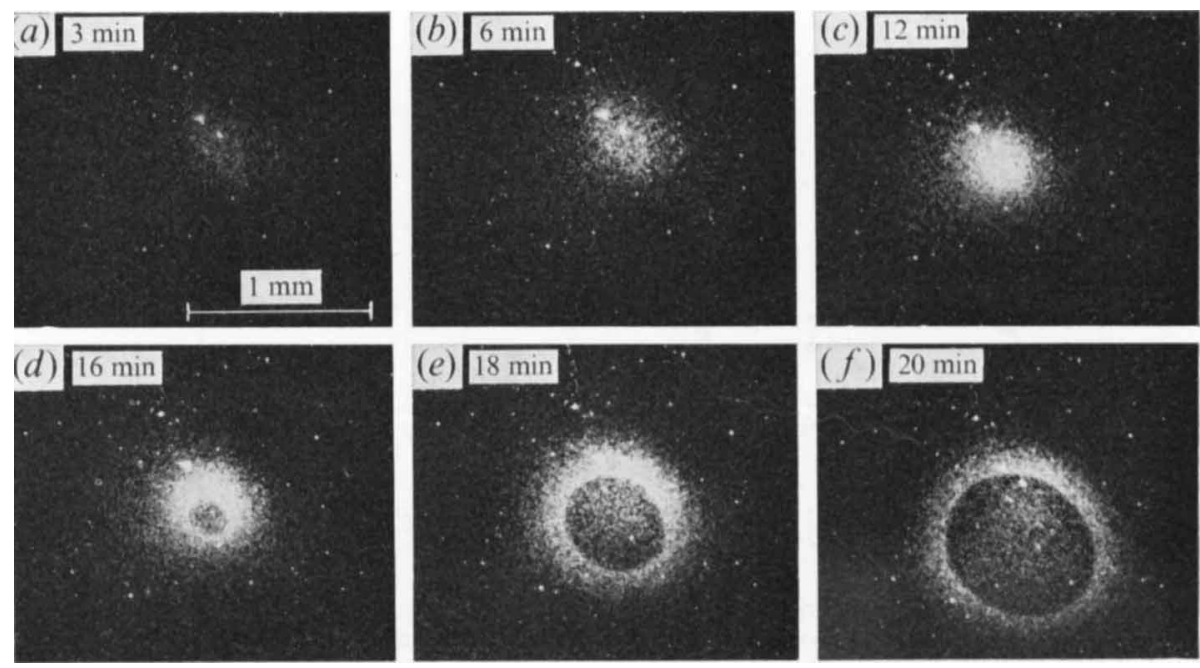

Fig. 2. Assembly of bacteria in a light spot and their subsequent dispersal after continued illumination. $(a-c)$ Assembly of bacteria. (d) Vacation of bacteria from the centre of the light spot. $(e, f)$ Bacterial ring extending towards the margin of the cover slip. Bacteria at a density of about $2 \times 10^{7}$ cells $/ \mathrm{ml}$ were observed and photographed with dark-field illumination. The visible light source was as in Fig. I.
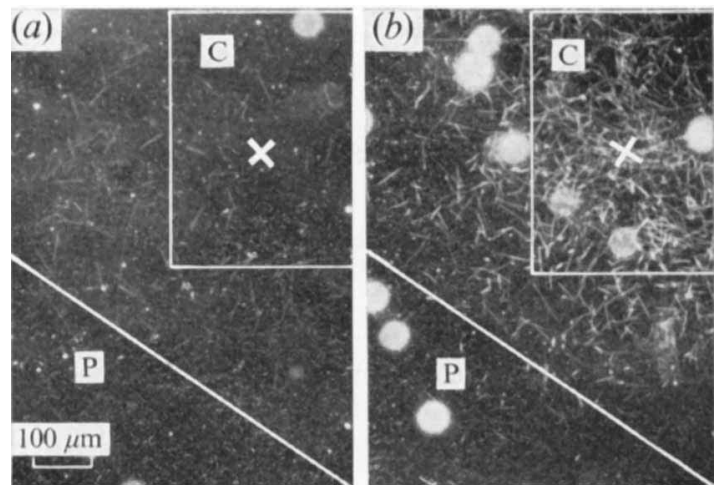

Fig. 3. Motility tracks and bacterial assembly in the central and peripheral areas of a light spot. (a) After I $\mathrm{min}$; (b) after $5 \mathrm{~min}$ illumination. There were about $5 \times 10^{7}$ bacteria $/ \mathrm{ml}$ : the visible light source was as in Fig. I. C, Central area; P, peripheral area; $\times$, centre of the light spot.

\section{Average time of run of bacteria under phototactic stimulation}

Bacteria either leaving or swimming towards the centre of the light spot were photographed and, from the tracks (Fig. 5), the fraction, $V_{0}$, of non-turning bacteria during the given time duration, $t$, was obtained for each group. The average time of run, $m$, i.e. the average time between two successive turns, was estimated from Poisson's formula $V_{0}=\mathrm{e}^{-t / m}$ assuming that each turn takes place randomly (Berg \& Brown, 1972).

Out of 70 tracks sampled for bacteria which were swimming towards the centre of the light spot at 0 time, 20 changed their swimming direction in $5 \mathrm{~s}$; of 66 tracks sampled for bacteria leaving the centre of the light spot at o time, 29 changed their swimming direction 


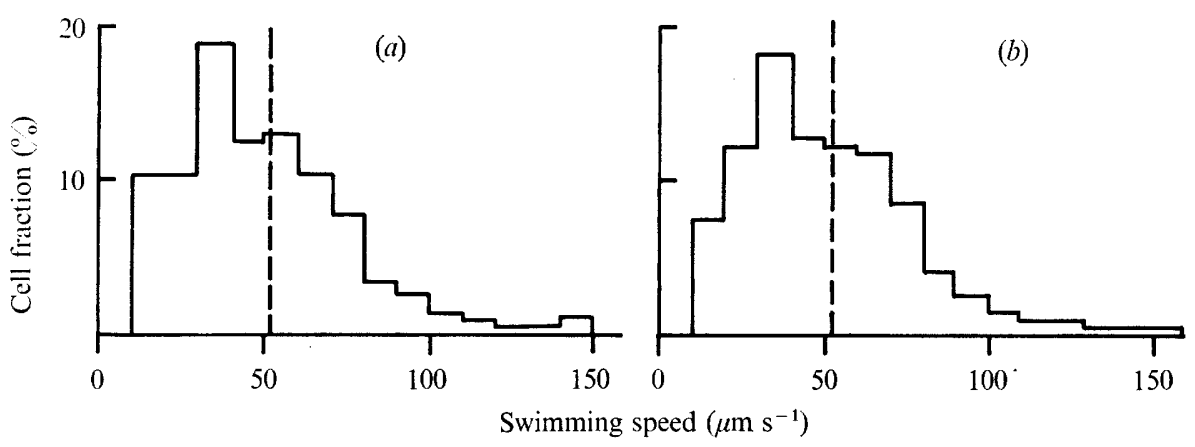

Fig. 4. Distribution of bacterial swimming speeds in the central and peripheral areas of a light spot. From the cinematograms shown in Fig. 3, swimming tracks of bacteria in the central and peripheral areas of the light spot were traced and swimming speeds were calculated. Mean speed values (vertical dashed lines) were $51 \mu \mathrm{m} \mathrm{s}^{-1}$ in the central $(a)$ and $53 \mu \mathrm{m} \mathrm{s}^{-1}$ in the peripheral $(b)$ areas of the light spot. In each case, 215 tracks were traced.

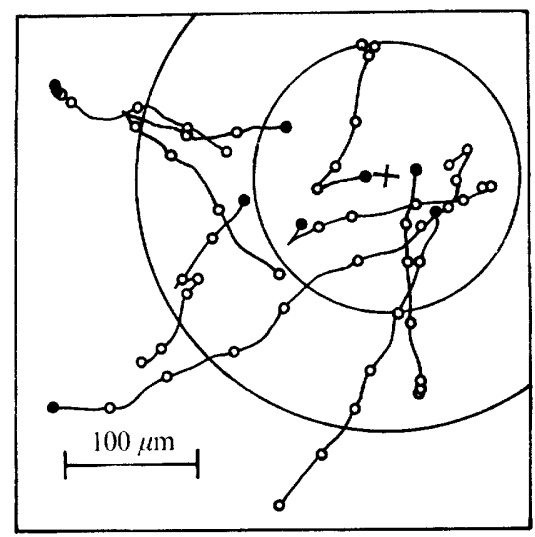

Fig. 5
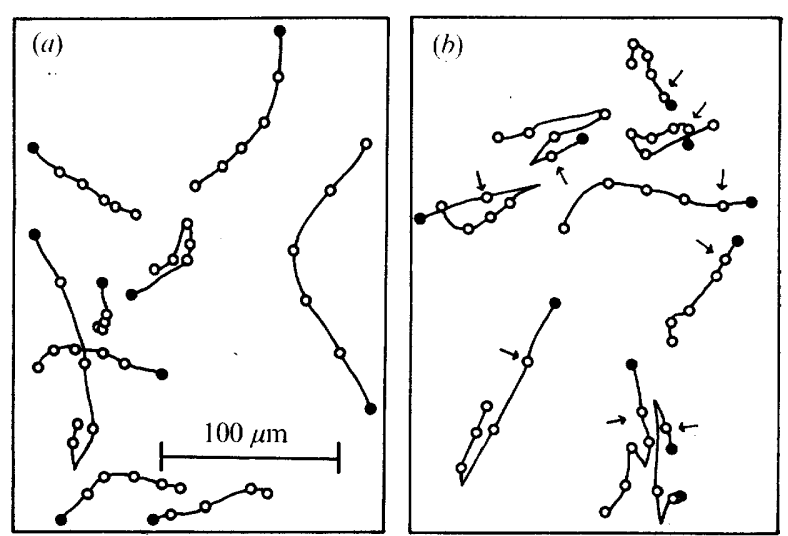

Fig. 6

Fig. 5. Tracks of bacteria swimming in the light gradient. $\times$, Centre of the light spot; $\bigcirc-\bigcirc$, cell positions at intervals of $0.5 \mathrm{~s} ; \boldsymbol{\theta}$, cell position at 0 time.

Fig. 6. Tracks of bacteria before and after a sudden change in intensity of the stimulating light. (a) $I \rightarrow I$; (b) $I \rightarrow \frac{1}{2} I$. $\bigcirc-\bigcirc$, Cell positions at intervals of $0.25 \mathrm{~s}$; 0 , cell position at o time; arrows indicate the cell positions when the abrupt change of stimulating light was made.

in $3 \mathrm{~s}$ (Table $\mathrm{I}$ ). Thus bacteria which were swimming towards the darker area changed direction three times more frequently than those swimming towards the brightest area.

According to Macnab \& Koshland (1972), bacteria sense the gradient of a tactic stimulus in space as a temporal change in the intensity of the stimulus while they are moving. To test this explanation for the present phenomenon, bacterial movements before and after a sudden change in the intensity of stimulating light were recorded (Fig. 6), and the resultant changes in frequency of turns were estimated. A sudden decrease or increase in the light intensity was achieved by inserting a neutral density filter (ND-50) into, or removing it from the light beam. Results are summarized in Table 2 and show that soon after the decrease, almost all bacteria changed their swimming direction, whereas after the increase, turning was almost completely repressed. 


\section{Table I. Change of swimming direction under constant light intensity}

Frequencies of non-turning bacteria swimming towards the margin or the centre of a light spot were examined on cinematograms recorded about $10 \mathrm{~min}$ after onset of illumination. Average durations of uni-directional swimming were calculated as described in Results. $V_{0}$ is the fraction of non-turning bacteria in $t \mathrm{~s}$, and $m$ the average duration of continuous swimming in the same direction.

$\begin{array}{lcccc}\text { Swimming direction } & \begin{array}{l}\text { Number } \\ \text { of tracks } \\ \text { sampled }\end{array} & t(\mathrm{~s}) & V_{0} & m(\mathrm{~s}) \\ \text { Towards light } & 70 & 5 & 0.71 & 15 \\ \text { Away from light } & 66 & 3 & 0.55 & 5\end{array}$

Table 2. Effect of sudden changes in light intensity on bacterial swimming

Tracks of bacteria under constant light intensity, and after a sudden change in light intensity, were traced on cinematograms as in Fig. 5 and the fraction of bacteria, $V_{0}$, which did not change their swimming direction in $I \mathrm{~s}$ was counted. The average time of run, $m$, was calculated as described in Results. The light intensities were about $5 \mathrm{~J} \mathrm{~cm}^{-2} \mathrm{~s}^{-1}(I)$ and about $2 \cdot 2 \mathrm{~J} \mathrm{~cm}^{-2} \mathrm{~s}^{-1}\left(\frac{1}{2} I\right)$.

$\begin{array}{ccccc}\begin{array}{c}\text { Light } \\ \text { intensity } \\ \text { changes }\end{array} & \begin{array}{c}\text { Tracks } \\ \text { examined }\end{array} & t \text { (s) } & V_{0} & m(\mathrm{~s}) \\ I \rightarrow I & \mathrm{I} 6 \mathrm{I} & \mathrm{I} & 0 \cdot 79 & 4 \\ \frac{1}{2} I \rightarrow \frac{1}{2} I & 77 & \mathrm{I} & 0 \cdot 78 & 4 \\ I \rightarrow \frac{1}{2} I & \mathrm{I} 19 & \mathrm{I} & 0 \cdot 27 & 0 \cdot 8 \\ \frac{1}{2} I \rightarrow I & 63 & \mathrm{I} & 0.97 & 20\end{array}$

\section{DISCUSSION}

Cells of $R$. rubrum cultivated anaerobically are pigmented and are capable of photosynthesis, but those cultivated aerobically lack the photosynthetic pigments (Oelze \& Drews, 1972). Previous studies on the phototaxis of $R$. rubrum were made exclusively with pigmented cells in which phototaxis could be induced by far-red light of wavelengths absorbed by bacteriochlorophyll. With non-pigmented $R$. rubrum, Uffen, Sybesma \& Wolfe (I97I) found no detectable phototactic response, a result which we confirmed under the same experimental conditions (unpublished data). However, when a light stimulus of higher intensity $\left(3 \mathrm{~J} \mathrm{~cm}^{-2} \mathrm{~s}^{-1}\right.$ of white light) was projected through a dark-field condenser, the bacteria moved towards the centre of the light spot. The photoreceptor responsible for this effect is not bacteriochlorophyll, because far-red light did not induce bacterial assembly whereas the same intensity of visible light did (Fig. I).

Light did not appear to change the swimming speed of the bacteria (Fig. 4). The data in Table I indicate that bacterial assembly was due to the tactic behaviour of individual organisms. The possibility that thermotaxis, a response to the temperature gradient produced by light, was the cause of this assembly is excluded by the fact that light which had passed through heat-absorbing filters permitted assembly, whereas far-red or infra-red radiation was inactive.

Light response of non-pigmented cells of $R$. rubrum was shown to be 'phobophototaxis', i.e. alteration of swimming direction due to temporal changes of light intensity, by the experiment in which the intensity was abruptly changed. Decreasing the intensity caused more frequent changes of swimming direction of bacteria, while increasing the intensity tended to keep bacteria swimming in the same direction. This characteristic of the 
response is similar to the phototaxis reported for pigmented cells of $R$. rubrum (Clayton, 1953b).

Thus light can induce a tactic response in this organism without the mediation of photosynthetic metabolism. Our preliminary results (unpublished) suggest that photoreduction of ferric ion in the medium is responsible for the induction of the tactic response.

We are grateful to K. Shimada for technical assistance in cinematography and K. Isono for criticisms of the manuscript.

\section{REFERENCES}

AdLer, J. (1966). Chemotaxis in bacteria. Science, New York 153, 708-716.

AdLER, J. (1969). Chemoreceptors in bacteria. Science, New York 166, 1588-1 597.

Adler, J. \& EPSTEIN, W. (1974). Phosphotransferase-system enzymes as chemoreceptors for certain sugars in Escherichia coli chemotaxis. Proceedings of the National Academy of Sciences of the United States of America 71, 2895-2899.

Aksamit, R. R. \& Koshland, JR, D. E. (1974). Identification of the ribose binding protein as the receptor for ribose chemotaxis in Salmonella typhimurium. Biochemistry 13, 4473-4478.

BERG, H. C. \& Brown, D. A. (1972). Chemotaxis in Escherichia coli analysed by three-dimensional tracking. Nature, London 239, 500-504.

Clayton, R. K. (1953a). Studies in the phototaxis of Rhodospirillum rubrum. I. Action spectrum, growth in green light, and Weber Law adherence. Archiv für Mikrobiologie 19, 107-124.

Clayton, R. K. (1953b). Studies in the phototaxis of Rhodospirillum rubrum. III. Quantitative relations between stimulus and response. Archiv für Mikrobiologie 19, I4I-165.

Clayton, R. K. (1959). Phototaxis of purple bacteria. In Handbuch der Pfanzenphysiologie, vol. I7, part I, pp. 37I-387. Edited by W. Ruhland. Berlin: Springer.

Clayton, R. K. (1964). Phototaxis in microorganisms. In Photophysiologie, vol. 2, pp. 51-77. Edited by A. C. Giese. New York and London: Academic Press.

Cohen-Bazire, G., Sistrom, W. R. \& Stanier, R. Y. (I957). Kinetic studies of pigment synthesis by nonsulphur purple bacteria. Journal of Cellular and Comparative Physiology 49, 25-68.

Engelmann, T. W. (1883). Bacterium photometricum. Pfü̈gers Archiv für die gesamte Physiologie 30, $95-124$.

FrENCH, C. S. (1937). The rate of $\mathrm{CO}_{2}$ assimilation by purple bacteria at various wavelengths of light. Journal of General Physiology 21, 7I-87.

HAUPT, W. (I966). Phototaxis in plants. International Review of Cytology 19, 267-299.

HAZelbauer, G. L. (1975). Maltose chemoreceptor of Escherichia coli. Journal of Bacteriology 122, $206-214$.

HAzelbauer, G. L. \& ADler, J. (1971). Role of the galactose binding protein in chemotaxis of Escherichia coli toward galactose. Nature, New Biology, London 230, I0I-I04.

MaCnAB, R. \& Koshland, JR, D. E. (1972). The gradient-sensing mechanism in bacterial chemotaxis. Proceedings of the National Academy of Sciences of the United States of America 69, 2509-25I 2.

MACNAB, R. \& KoshlaND, JR, D. E. (1974). Bacterial motility and chemotaxis: light-induced tumbling response and visualization of individual flagella. Journal of Molecular Biology 84, 399-406.

MANTEN, A. (1948). Phototaxis in purple bacterium Rhodospirillum rubrum and the relation between phototaxis and photosynthesis. Antonie van Leeuwenhoek 14, 65-86.

Metzner, P. (1920). Die Bewegung und Reizbeantwortung der bipolar begeißelten Spirillen. Jahrbuch für wissenschaftliche Botanik 59, 325-4I2.

Milatz, J. M. W. \& Manten, A. (I953). The quantitative determination of the spectral distribution of phototactic sensitivity in the purple bacterium Rhodospirillum rubrum. Biochimica et biophysica acta II, 17-27.

NultsCH, W. (1970). Photomotion of micro-organisms and its interactions with photosynthesis. In Photobiology of Micro-organisms, pp. 213-25I. Edited by P. Halldal. New York: Wiley-Interscience.

Oelze, J. \& DRews, G. (I972). Membranes of photosynthetic bacteria. Biochimica et biophysica acta 265, 209-239.

TANIGUCHI, S. \& KaMEN, M. D. (1965). The oxidase system of heterotrophically-grown Rhodospirillum rubrum. Biochimica et biophysica acta $96,395-428$.

Thimann, K. V. \& Curry, G. M. (1960). Phototropism and phototaxis. In Comparative Biochemistry, vol. I, pp. 243-309. Edited by M. Florkin and H. S. Mason. New York and London: Academic Press.

Thomas, J. B. (1950). On the role of the carotenoids in photosynthesis in Rhodospirillum rubrum. Biochimica et biophysica acta $5,186-196$.

UfFen, R. L., Sybesma, C. \& Wolfe, R. S. (I97I). Mutants of Rhodospirillum rubrum obtained after longterm anaerobic, dark growth. Journal of Bacteriology 108, 1348-1 356. 